\title{
Infectious and Noninfectious Pulmonary Complications in Patients With Primary Immunodeficiency Disorders
}

\author{
Yazdani $\mathrm{R}^{1,2,3}$, Abolhassani $\mathrm{H}^{2,4}$, Asgardoon $\mathrm{MH}^{2}$, Shaghaghi $\mathrm{M}^{2,5}$, Modaresi $\mathrm{M}^{6}$, \\ Azizi $\mathrm{G}^{7}$, Aghamohammadi $\mathrm{A}^{2}$
}

\author{
'Department of Immunology, School of Medicine, Isfahan University of Medical Sciences, Isfahan, Iran \\ ${ }^{2}$ Research Center for Immunodeficiencies, Children's Medical Center, Tehran University of Medical Sciences, \\ Tehran, Iran \\ ${ }^{3}$ Molecular Immunology Interest Group (MIIG), Universal Scientific Education and Research Network (USERN), \\ Isfahan, Iran \\ ${ }^{4}$ Division of Clinical Immunology, Department of Laboratory Medicine, Karolinska Institutet at Karolinska \\ University Hospital Huddinge, Stockholm, Sweden \\ ${ }^{5}$ Network of Immunology in Infections, Malignancy and Autoimmunity (NIIMA), Universal Scientific Education \\ and Research Network (USERN), Tehran, Iran \\ ${ }^{6}$ Department of Pediatric Pulmonary and Sleep Medicine, Children Medical Center, Teharn University of Medical \\ Sciences, Tehran, Iran \\ ${ }^{7}$ Imam Hassan Mojtaba Hospital, Alborz University of Medical Sciences, Karaj, Iran
}

J Investig Allergol Clin Immunol 2017; Vol. 27(4): 231-224

doi: 10.18176/jiaci.0166

\begin{abstract}
Primary immunodeficiency disorders (PIDs) are caused by 1 or more defects of the immune system. Patients are more likely to experience recurrent and/or severe infections and tend to develop a wide range of complications. Respiratory diseases are the main and initial manifestation in most cases and the most common complication. Pulmonary complications cause significant morbidity and mortality in patients with PIDs. Early diagnosis and appropriate treatment can prevent or at least slow the development of respiratory complications. Since the spectrum of pulmonary complications in PIDs is broad, we divided pulmonary complications into upper respiratory complications (eg, sinusitis, otitis media, and laryngeal angioedema) and lower respiratory complications (eg, pneumonia, bronchitis, bronchiectasis, interstitial lung diseases, organizing pneumonia, pulmonary adenopathies and malignancies, hyperreactive airway diseases, pulmonary dysgenesis, and adverse reactions to treatment). This review covers the main respiratory manifestations in patients with PIDs.
\end{abstract}

Key words: Primary immunodeficiency disorders. Pulmonary complications. Upper respiratory tract. Lower respiratory tract.

\section{Resumen}

Las inmunodeficiencias primarias (PIDs) son enfermedades causadas por uno o más defectos del sistema inmunológico. Estos pacientes presentan con frecuencia infecciones recidivantes y/o severas así como otro tipo de complicaciones. Las patologías respiratorias son la principal y más frecuente manifestación y complicación de las PIDs. Las complicaciones de estas patologías pulmonares constituyen una de las principales causas de morbimortalidad entre los pacientes que sufren PIDs. El diagnóstico temprano y el tratamiento adecuado pueden prevenir, 0 al menos retrasar, la aparición de las complicaciones respiratorias en estos pacientes. Dado que el espectro de las enfermedades pulmonares es muy amplio, hemos dividido estas complicaciones entre aquellas que afectan a las vías aéreas superiores (sinusitis, otitis media y angioedema laríngeo, etc.) y las que afectan a las vías aéreas bajas (neumonía, bronquitis, bronquiectasias, enfermedades pulmonares intersticiales, neumonía organizada, adenopatías pulmonares y neoplasias, hiperreactividad bronquial, disgenesia pulmonar y las debidas a los efectos secundarios del tratamiento instaurado). Este artículo revisa las manifestaciones respiratorias que se observan más frecuentemente en los pacientes con PIDs.

Palabras clave: Inmunodeficiencias primarias. Complicaciones pulmonares. Vías respiratorias altas. Vías respiratorias bajas. 


\section{Introduction}

Primary immunodeficiency disorders (PIDs) are a heterogeneous group of genetic disorders caused by 1 or more abnormalities of the immune system. PIDs range from mild to severe forms of immunodeficiency such as severe combined immunodeficiency (SCID). Although the main clinical presentations are recurrent and chronic infections, patients also have an increased incidence of autoimmunity, lymphoproliferative disorders, and cancers [1-4]. The incidence and prevalence of PIDs are unknown, although they are estimated to affect between 1:10 000 and 1:600 individuals in over 40 countries [5]. Recent advances in molecular genetics and immunology have led to the detection of several causative genes and a better knowledge of the pathogenesis of PIDs. More than 300 PIDs have been identified to date, thus expanding the range of deficiencies to immune dysregulation, autoinflammatory disorders, and defects in innate and intrinsic immunity [6]. Immunoglobulin replacement therapy is a lifesaving intervention for many patients with PID, although antibiotics, immunomodulators, and hematopoietic stem cell transplantation (HSCT), can be used under specific conditions [7].

Pulmonary complications are common in patients with PID and contribute significantly to morbidity and mortality. Recurrent respiratory infections are often the first warning sign and are major causes of death. The spectrum of respiratory manifestations is extremely wide, including acute and chronic infections (eg, recurrent, severe, persistent infections affecting various locations, and opportunistic or unusual pathogens), immune dysregulation (eg, autoimmunity, allergy, and lymphoproliferative disorders), structural abnormalities, and malignancies. As survival from infection improves (mortality from PID is still 30\%-45\% worldwide), noninfectious pulmonary complications are more frequently observed among patients with PIDs $[8,9]$. Standard management of the respiratory complications of PID is complemented by more specific therapeutic modalities, including surgery (otitis, sinusitis, adenoiditis, and lung infection), lung transplantation, and symptomatic therapies (anti-inflammatory drugs, mucolytics, bronchodilators, and inhalers). Since respiratory disorders are a significant cause of morbidity and the leading cause of death (30\%-65\%) in both children and adults with PIDs, timely diagnosis and appropriate therapy can improve or at least decelerate the progression of these complications [10-12]. The aim of this study was to review upper and lower respiratory tract complications in patients with PID.

\section{Upper Respiratory Tract}

The upper respiratory tract complications of PID include acute and chronic infections (rhino/sinusitis, otitis media, pharyngitis, laryngitis, tonsillitis, and epiglottitis), upper airway anatomical defects (obstruction due to angioedema, obstruction and destruction of the nasal septum mostly secondary to fungal infections in combined immunodeficiency), atopic reactions (allergic rhinitis, mostly in antibody deficiencies), and lymphoproliferative disorders (adenitis or lymphadenitis, mostly in antibody deficiency and immune dysregulation). The most frequent complications are sinusitis, otitis media, and laryngeal angioedema, which are described below.

\section{Sinusitis}

Sinusitis (also known as rhinosinusitis) is defined as a common inflammatory condition of the paranasal sinuses and nasal cavity that can be acute or chronic ( $>12$ weeks). Sinusitis is diagnosed based on clinical signs and symptoms, including chronic nasal obstruction, mucopurulent rhinorrhea, postnasal discharge, and cough [13]. Serious sinus infections (more than 2 in childhood and 4 in adulthood) within 1 year are 1 of the 10 warning signs of PID proposed by the Jeffrey Modell Foundation [14]. Chronic sinusitis is very frequent in PID patients [15], although this frequency varies with the type of study and PID, as shown in a systematic review where $10 \%-54 \%$ of patients with chronic sinusitis had PID [16]. We previously demonstrated that sinusitis was the most common ear, nose, and throat presentation in patients with primary antibody deficiency (PAD) [17]. The most frequent PID associated with sinusitis is humoral immunodeficiency. This disorder includes selective IgA deficiency (SIgAD), common variable immunodeficiency (CVID), and specific antibody deficiency (SAD), which is characterized by normal IgG levels but an impaired response to polysaccharide vaccines [17-21]. One study reported considerable differences in the incidence of sinusitis in PIDs, such as agammaglobulinemia (11.52\%), CVID (9.4\%), SAD (1.8\%), IgG subclass deficiency (13.41\%), SIgAD (6.58\%), and hyper-IgM syndrome (0.7\%) [19]. The manifestation of recurrent sinusitis in patients with immune dysregulation (especially PAD patients) demonstrates the importance of immunological testing in patients with recurrent sinusitis [22]. The Table shows some of the bacteria involved in sinusitis in PID patients.

Recurrent rhinosinusitis has a strong negative impact on quality of life [23]. Immunological tests in patients with recurrent sinusitis comprise measurement of antibody levels ( $\mathrm{IgG}, \operatorname{IgA}$, and $\operatorname{IgM}$ ), preimmunization and postimmunization specific antibody responses to tetanus toxoid and pneumococcal polysaccharide vaccines, $\mathrm{CH} 50$ testing, and determination of T-cell count and function (delayed hypersensitivity skin tests and flow cytometric enumeration of $\mathrm{T}$ cells). IgG subclasses should not be checked routinely when evaluating immunodeficiency, as the association between IgG subclass deficiency and recurrent sinusitis is controversial and the clinical significance of abnormal IgG subclasses in patients with recurrent infections is unclear [24]. Only a few studies have investigated the treatment of chronic sinusitis in patients with PIDs, although it seems that treatment involves both medical and surgical approaches, as occurs in immunocompetent individuals. In general, broad-spectrum antibiotics, saline nasal washes, anti-inflammatory agents, and immunoglobulin replacement therapy could reduce the frequency and severity of sinusitis in PID patients [18,25]. While the role of sinus surgery has not been well defined, it seems that PID patients experience similar benefits to immunocompetent populations in terms of symptoms and quality of life [26-29]. If the response to surgery of patients with PID is similar to that of the general population with chronic sinusitis, earlier surgery has been shown to decrease the harmful effects of chronic sinusitis [30]. 
Table. Microorganisms Involved in Infectious Pulmonary Complications of Primary Immunodeficiency

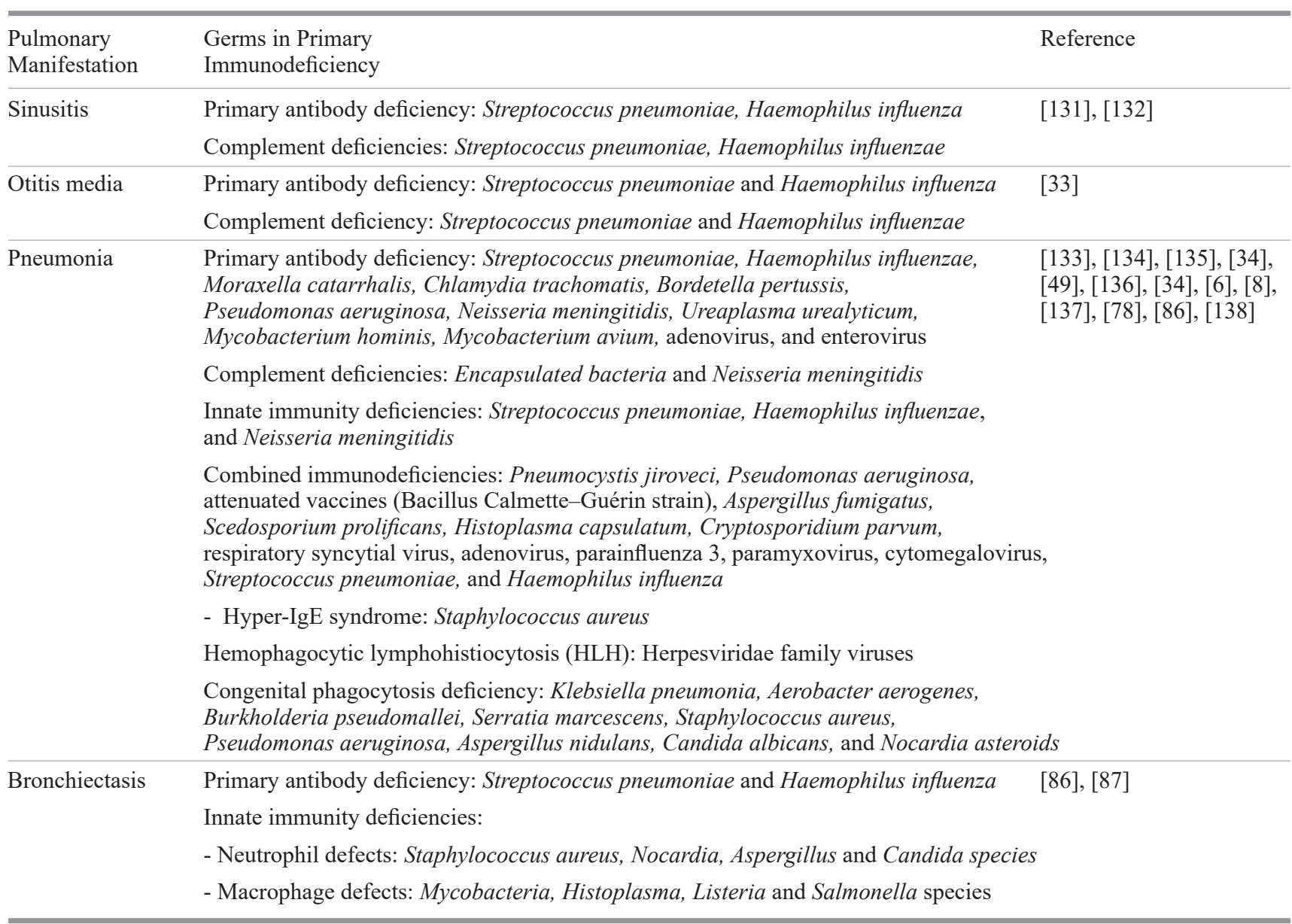

\section{Otitis Media}

Otitis media is an infection or inflammation of the middle ear that may point to a variety of underlying problems. This disease affects both children and adults, although it is less common in adults owing to the anatomical development of the upper airways. Four or more serious ear infections in a year are 1 of the 10 warning signs of PID proposed by the Jeffrey Modell Foundation [14]. Recurrent otitis media is considered to be one of the most common infections in PID, although its frequency varies between the different forms of PIDs. Yarmohammadi et al [15] reported a high rate of otitis media in patients with PID (81 of 113 patients, $71.6 \%$ ), which was significantly higher than in patients without immune defects. Owayed and Al-Herz [31] found the rate of otitis media to be lower (59 of 202 patients, $29.2 \%$ ). In the third report of the Iranian registry, we reported 46 cases in 731 patients $(6.3 \%)$ in whom the first presentation of PID was otitis media [3].

Conley and Howard [32] indicated that almost all of the patients who had X-linked agammaglobulinemia (XLA) after the first year of life had a history of recurrent otitis media. Other studies have also reported a high rate of otitis media in XLA patients [31-34]. In one study, we demonstrated that $81.1 \%$ of XLA patients manifested acute otitis media. Although this was the second most common infectious disease among Iranian XLA patients, chronic otitis media was the most common complication among chronic manifestations [35]. We found a lower rate of otitis media in CVID patients with hypogammaglobulinemia than in those with agammaglobulinemia $[17,36]$. This rate was higher in other studies [37-39], although this difference could be due to differences in the number of patients in each study (high in our study). Moreover, since B cells and secondary lymphoid organs are present in CVID patients, in contrast with patients with agammaglobulinemia, a lower rate of otitis media could be logical in CVID. Otitis media is more common in children with CVID than in adults, probably as a result of the anatomic characteristics of the upper airways in children [37]. Patients with a defect in polysaccharide antibody production (with or without IgG subclass deficiency) are very prone to otitis media $[40,41]$. Infection is more severe in patients with a defect in polysaccharide antibody production associated with IgG subclass deficiency and SIgAD [42-44]. IgG2 may protect against polysaccharides, because it has been indicated that patients with low IgG2 had recurrent episodes of otitis media despite exhibiting normal levels of $\operatorname{IgA}$, IgM, IgG and IgG1 [45]. Sinopulmonary complications such as otitis media are more common in PAD than in combined immunodeficiency 
(CID). This difference could be due to disease severity, because PAD patients live longer and are therefore more likely to develop complications than patients with CID. Moreover, in comparison with patients with PAD, those with CID have very low levels of IgA, which is vital for mucosal immunity in the respiratory and gastrointestinal tracts. The Table shows some of the bacteria involved in otitis media in patients with PID.

\section{Laryngeal Angioedema}

Angioedema is characterized by localized swelling that is generally asymmetric owing to increased vascular permeability with leakage of plasma. While this complication can involve all mucosal layers and subcutaneous tissues, in the respiratory tract, it can cause potentially life-threatening obstruction and asphyxiation. Several types of PID should be considered in patients with hereditary angioedema (HAE). Monogenic disorder of the complement system due to decreased level or dysfunction of $\mathrm{C} 1$ esterase inhibitor $(\mathrm{C} 1 \mathrm{INH})$ has been estimated to have a prevalence of 1 case per 50000 individuals. It is important to distinguish between HAE and acquired angioedema in order to modify management and treatment of patients, which can differ for each group and should include purified or recombinant $\mathrm{C} 1 \mathrm{INH}$ and bradykinin receptor antagonists.

\section{Lower Respiratory Tract}

Lower respiratory tract complications are considered to be clinically more important and more specific, thus facilitating determination of pathogenesis and prognosis. These complications comprise a wide range of infectious conditions (eg, bronchitis, pneumonia, empyema, and lung abscess) and noninfectious conditions (eg, hilar/mediastinal adenopathies, and obstructive and restrictive lung diseases) [46,47]. The development of noninfectious manifestations of the lower respiratory tract is usually multifactorial owing to immune dysregulation (eg, chronic inflammation, autoimmunity, and allergy), adverse effects of therapies, and malignancies [8]. Lower respiratory tract complications are examined in the following sections.

\section{Pneumonia}

Pneumonia is an inflammatory condition of the lung that is most often caused by infection in patients with PID (opportunistic organisms such bacteria, viruses, fungi [Pneumocystis jiroveci]), although it can also be noninfectious. Pneumonia as a complication of the lower respiratory tract is one of the most frequent manifestations of PID and determines prognosis. Frequent pneumonia (more than 2 episodes in a year for children and in 3 years for adults) is 1 of the 10 general warning signs of PID suggested by the Jeffrey Modell Foundation [14], and retrospective studies have shown pneumonia to be the top presenting feature in PID $[48,49]$. In a cohort study, we demonstrated that pneumonia was the most common first presentation of PID in $23.4 \%$ of patients [3].

Recurrent pneumonia is one of the most common and characteristic signs of PAD. Almost two-thirds of CVID patients have experienced at least 1 episode of pneumonia before diagnosis, and many experienced multiple prior episodes [49-51]. A recent large-scale study found that pneumonia was the most frequent manifestation in 2212 CVID patients [52]. The authors demonstrated that levels of IgG were lower in patients with recurrent pneumonia than in patients without pneumonia, indicating that the risk of pneumonia increases if patients have a low serum IgG level. A high rate of pneumonia has been also observed in patients with XLA $(62 \%)$ [34]. This finding is consistent with the pattern of initial presentation in patients with CVID and XLA after the first 6 months of life, when maternal IgG decreases. Different incidence rates of pneumonia have been also reported in other forms of PID such as X-linked hyper-IgM syndrome (81\%) [53], NEMO deficiency (31\%) [54], and WiskottAldrich syndrome (45\%) [55]. The microorganisms involved in pneumonia in PID patients are shown in the Table.

In patients with PID, pneumonia can be severe and require high-dose immunoglobulin replacement therapy, intravenous antibiotics, and/or hospitalization. Immunoglobulin replacement therapy is useful in PID patients with pneumonia, as it increases the level of IgG to at least the mid-normal range [56]. By preventing pneumonia, treatment with immunoglobulin can also decrease accompanying complications, such as bronchiectasis and chronic lung disease. Given the broad spectrum of pathogens implicated in CID and phagocytosis defects, every effort should be made to identify a causative organism to ensure accurate antibiotic treatment. In cases of cavitation owing to necrosis or fungal infection, the air crescent sign can be observed on the radiograph. Recombinant granulocyte colony-stimulating factor in phagocytosis defects and HSCT for CID patients could lead to a reduction in the frequency of these complications [57].

Noninfectious pneumonia has been reported in adenosine deaminase deficiency (a CID disease caused by accumulation of adenosine in the alveoli) [58], pulmonary alveolar proteinosis (a phagocytosis defect due to CSF2RA and GATA2 deficiency and accumulation of surfactant in the alveoli), and aspiration pneumonia in syndromic CID with neurological defects (eg, ataxia-telangiectasia, Nijmegen breakage syndrome, and other DNA repair defects) [6].

\section{Bronchitis}

Acute bronchitis is characterized by cough due to acute inflammation of the trachea and large airways when there is no evidence of pneumonia [59]. Cough associated with acute bronchitis typically lasts about 2 to 3 weeks and is usually the chief complaint of patients referred to clinics [59]. Many patients with bronchitis fail to respond to appropriate treatment and are referred to physicians with chronic productive cough. This should therefore be differentiated from chronic bronchitis, which lasts about 2 to 3 weeks [25]. The clinical picture of PID is not distinctive, and symptoms may be difficult to detect at the clinical level. Approximately $70 \%$ to $80 \%$ of patients experience recurrent respiratory infections, including bronchitis [60].

As occurs in pneumonia (the most frequent type of PID) patients with antibody deficiencies are at increased risk of bronchitis. Karaulov et al [61] demonstrated that $54.4 \%$ of CVID patients presented bronchitis as the first 
manifestation [61]. Plebani et al [62] reported that lower respiratory tract infections were most frequent in patients with XLA and that $78 \%$ of patients had bronchitis. In milder forms of humoral immunodeficiency, recurrent bronchitis manifests in IgG3 deficiency, the most common subclass deficiency (88.1\%), and IgG4 deficiency (15.3\%) [63]. IgG subclass deficiency is characterized by exacerbation-prone phenotypes, decline in lung function, and subsequent poor prognosis [63]. Although these patients did not manifest evidence of pneumonic infiltration on chest x-ray, they were diagnosed as having recurrent bronchitis, which was defined as $\geq 3$ episodes of acute bronchitis per year [63]. In North American and European studies, antibiotic treatment has not been shown to benefit patients with acute bronchitis, and antibiotic treatment is not recommended for this condition in immunocompetent or immunocompromised patients in developed countries [64].

\section{Bronchiectasis}

Bronchiectasis is characterized by chronic and abnormal dilation of the airways and is caused by impaired clearance of various microorganisms and recurrent infection. Previous studies show that $26 \%-53 \%$ of cases of bronchiectasis have no known cause $[65,66]$. Chronic airway inflammation is supposed to be the primary cause of bronchiectasis, as observed in a condition that involves the airways, such as recurrent pulmonary infections, and autoimmune disease. PID is a common cause of recurrent bronchiectasis. Indeed, PID contributes to increased susceptibility to pulmonary infections and chronic inflammatory airways, which in turn lead to bronchiectasis. This condition is characterized by obstructive or mixed patterns in pulmonary function tests in patients with PID, is generally observed in the lower or middle lobes, and is predictive of a poor prognosis.

Most patients with hypogammaglobulinemia experience the mild type of bronchiectasis [67]. Patients with PADs are at a significantly increased risk for developing bronchiectasis $[65,68,69]$, as we indicated in a study in which $37.5 \%$ of patients with bronchiectasis were diagnosed with defects in antibody-mediated immunity [70]. The exact prevalence of bronchiectasis in patients with PAD is unclear, although a systematic review has reported that bronchiectasis manifests in $17 \%-76 \%$ of cases, usually with a tubular/ cylindrical pattern affecting the proximal bronchi [71]. More than $70 \%$ of CVID patients develop bronchiectasis and bronchial wall thickening $[47,72]$, indicating that bronchiectasis is a well-recognized complication of CVID. The incidence of bronchiectasis in patients with XLA is almost $32 \%$, although XLA has been associated with up to $3 \%$ of cases of childhood bronchiectasis [73-75] and is rare in adults. We indicated that the rate and severity of bronchiectasis were greater in CVID patients than in those with XLA, probably because of the earlier diagnosis and treatment of XLA patients [76]. Moreover, CVID patients had a greater likelihood of developing lung disease, possibly owing to delayed diagnosis and immune dysregulation, as compared with XLA patients [76]. Mild to severe vitamin D deficiency in CVID patients is considered to be associated with a risk of bronchiectasis. In the milder form of PAD (eg, SIgAD and IgG subclass deficiencies), the prevalence of bronchiectasis is much lower than that of XLA and CVID. IgG subclass deficiency, particularly that of IgG2, has been associated with bronchiectasis in children [77]. Given that the incidence of bronchiectasis in patients with IgG subclass deficiency varies widely (anywhere from $4 \%$ to nearly $50 \%$ ), it is difficult to establish a correlation between bronchiectasis and $\operatorname{IgG}$ subclass deficiency [65,69,77-79]. In one study, SAD was reported in $58 \%$ of patients with idiopathic bronchiectasis [80]. However, the study was small, with no matched controls in which the immunological criteria used for SAD were queried [81]. Other larger series of adult patients with bronchiectasis show that the incidence of specific antibody deficiency varies from $4 \%$ to $11 \%[65,82]$. Antibody responses to polysaccharide vaccines are variable and depend on age. Furthermore, up to $10 \%$ of the healthy population may be nonresponders [75,83]; consequently, it is difficult to evaluate $\mathrm{SAD}$ as a cause of bronchiectasis without further studies involving large numbers of bronchiectasis patients and matched controls.

The incidence of bronchiectasis in other rare PIDs such as hyper-IgE syndrome $(<2.5 \%$ in children and very rare in adults) $[74,84,85]$, phagocyte defects $(<1 \%-10 \%$ in children and $<1 \%$ in adults) $[86,87]$, and transporter antigen peptide deficiency (rare in children and very rare in adults) $[87,88]$ is low. The microorganisms associated with bronchiectasis in patients with PID are shown in the Table.

High-resolution computed tomography (HRCT) is considered a reliable test for assessing bronchiectasis in patients with PID [89-91]. HRCT should be used in all patients with chronic chest symptoms to monitor disease progression. Findings such as bronchial dilatation, signet ring sign (large airway involvement), tree-in-bud sign (small airway involvement), mucopurulent plugs, bronchial wall thickening, lack of tapering, and bronchi visible closer than $2 \mathrm{~cm}$ to the pleural surface are considered characteristic of bronchiectasis [92]. Since we and others demonstrated that patients with DNA repair defects and some CVID patients show increased radiation sensitivity [93-95], a radiation-free alternative to CT scan or chest X-ray could be magnetic resonance imaging to assess pulmonary changes and alterations [96]. Recognizing the cause of bronchiectasis may improve management and prognosis, eg, initiation of immunoglobulin replacement in PAD patients, which may prevent the progression of irreversible lung damage. While patients with bronchiectasis require higher doses to achieve a satisfactory trough level, the intravenous route is more commonly recommended for administration of immunoglobulin.

\section{Interstitial Lung Disease}

Interstitial lung disease (ILD) comprises a group of chronic inflammatory diseases that are major complications of PIDs. ILD is symptomatic in later stages and is associated with pulmonary fibrosis. In advanced stages, patients can develop pulmonary hypertension, cor pulmonale, and respiratory failure. In PID patients with a recurrent respiratory infection, ILD is more frequent and much more prevalent than expected in the general population, especially in antibodydeficient individuals. IgG subclass deficiency and SIgAD, 
respectively, are the most and least common immune disorders associated with ILD. However, some specific PIDs (eg, ataxia telangiectasia and chronic granulomatous disease) have been associated with greater susceptibility to ILD [98]. They rarely occur in childhood but represent a large number of conditions involving the parenchyma of the lung including the alveoli, the alveolar epithelium, the capillary endothelium, and the spaces between those structures, as well as perivascular and lymphatic tissue. These disorders are associated with considerable rates of morbidity and mortality. ILD comprises nonmalignant disorders that are generally not caused by identified infectious agents. Moreover, there is little consensus regarding management of most types of ILD.

Many types of PID carry an increased risk of systemic autoimmune disorders that involve respiratory interstitial tissue. Autoimmunity-associated ILD may be more responsive to treatment than idiopathic forms, particularly with targeted therapy using rituximab or anti-tumor necrosis factor (TNF) agents. The main PIDs that manifest with systemic autoimmune disorders are PAD (associated with rheumatoid arthritis, systemic lupus erythematosus, polymyositis, vasculitis, Sjögren syndrome, and scleroderma), phagocytosis defects (antiphospholipid syndrome), and complement deficiencies (systemic lupus erythematosus and vasculitis).

A decrease in the diffusing capacity of the lungs for carbon monoxide could be an early sign of progression to a restrictive lung disease or ILD and should be monitored using additional spirometry testing [99]. In imaging, lung ultrasound is reported to be a sensitive tool for detection of ILD, and combining chest $\mathrm{x}$-ray and lung ultrasound for further evaluation provides various complementary features. The combination of both approaches could reduce the need for HRCT [100]. However, HRCT is the diagnostic choice for early detection and confirmation of suspected ILD, better evaluation of the extent and distribution of disease, and identification of coexisting complications [101]. Antifibrotic agents, especially pirfenidone and nintedanib, can be used in patients with ILD [10].

Granulomatous-lymphocytic interstitial lung disease (GLILD) is defined as the pulmonary manifestation of a multisystem disease and is an umbrella term encompassing lymphocytic intestinal pneumonia, follicular bronchiolitis, pulmonary nodular lymphoid hyperplasia, and reactive lymphoid infiltrates [102,103]. GLILD is frequently accompanied by diffuse autoimmune cytopenia, adenopathy, splenomegaly, and extrapulmonary granulomatous disease, which mainly affects the lymph nodes, spleen, liver, and gastrointestinal tract. The etiology of noncaseating granuloma formation remains unknown, although an increase in levels of TNF, human herpesvirus 8, Epstein-Barr virus, and cytomegalovirus has been proposed [104,105]. No studies report GLILD in XLA, suggesting that T-cell dysfunction is the probable pathogenic mechanism. Hypomorphic mutations in recombination-activating gene $1(R A G 1)$, haploinsufficiency of cytotoxic T lymphocyte antigen-4 (CTLA4), and deficiency in lipopolysaccharide responsive beige-like anchor protein $(L R B A)$ has been described in patients with GLILD [106].

Of all the ILDs associated with PID, GLILD is the most common, the most widely investigated, and the most closely associated with poor clinical outcomes. The incidence of granulomas in CVID has been estimated to be between $5 \%$ and
$20 \%$ in various cohorts [107-109]. In patients with PID, GLILD manifests with the gradual development of dyspnea on exertion and cough or may be asymptomatic. The presence of GLILD in PID patients points to a poorer prognosis and increases the prevalence of lymphoproliferative disorders [110]. The finding of interstitial fibrosis (with or without architectural remodeling) requires additional study for its effect on prognosis [111]. The typical imaging pattern of ILD in PAD is a generalized diffuse reticular change and consolidation, with or without a groundglass appearance, predominantly in the lower lobe.

In a recent study [112], positron emission tomography (PET)-CT scanning using fludeoxyglucose was used to assess and monitor the response to treatment in CVID patients with GLILD. The authors found a widespread and high level of metabolic activity in the lungs and lymph nodes, thus suggesting the potential utility of this imaging modality in this subset of patients. In order to decrease the delay in diagnosis, increase early detection, and prevent disease progression, it has been recommended to screen all symptomatic and asymptomatic CVID patients for lung disease [113]. The choice of treatment should be based on the presence of symptoms, history of an inciting medication, extent of extrapulmonary involvement, and careful assessment of the histopathologic grade of the lesion. Immunoglobulin replacement therapy seems to be an effective and satisfying strategy and is also the oldest modality for prevention of progression of GLILD in various forms of PID. However, corticosteroids are the first-line approach in several studies and have been maintained until pulmonary function tests and radiology findings show an improvement in the patient's condition. In some studies, combination therapies are indicated for patients with GLILD in order to achieve a complete response, because statistics show that although many patients respond well to high-dose corticosteroids, this modality is not effective in some cases [114].

\section{Organizing Pneumonia}

Organizing pneumonia (OP), formerly known as bronchiolitis obliterans OP (BOOP), is a relatively rare presentation in PID. It involves a nonspecific response of the bronchial epithelium to infections (particularly those caused by Mycoplasma species), inflammation (autoimmunity, post-HSCT), and fibrosis. OP is clinically characterized by concentric luminal narrowing leading to subacute illness with dyspnea and cough and resting hypoxemia in advanced stages of fibrosis, with a mixed obstructive and restrictive pattern in pulmonary function tests.

OP has been reported in CID and PAD patients $[72,115,116]$. Rao et al [111] evaluated CVID patients and reported OP in $87.5 \%$, mostly in mild forms of the disease. Pulmonary function tests reveal a mild-to-moderate restrictive pattern. We previously reported OP in childhood as a complication of PID due to an $L R B A$ mutation and suggested that mutations in this gene could lead to a variety of immunodeficiencies, ranging from immunoglobulin deficiency to low B-cell count [117].

The diffusing capacity of the lung for carbon dioxide is usually reduced in patients with fibrosis. The chest CT scan shows a typical pattern of bilateral patchy alveolar infiltration. Inspiratory and expiratory HRCT images have been recommended to identify air trapping downstream from the obstruction and show scattered bilateral alveolar opacities 
and ground-glass consolidation in the presence of cryptogenic OP. The histological diagnosis can be made by transbronchial lung biopsy, although open lung biopsy might sometimes be required, as the disease may go undiagnosed in small specimens. Histologically, OP is characterized by Masson bodies, which are spherical proliferations of loose collagenembedded fibroblasts and myofibroblasts set in a pale, myxoid stroma located within airspaces and the adjacent interstitium. Analysis of bronchoalveolar lavage fluid typically reveals foamy macrophages and an increase in counts of all cell types, mainly lymphocytes and plasma cells in the interstitium.

\section{Pulmonary Adenopathies and Malignancies}

Localized hilar and/or mediastinal adenopathies can be seen in the context of lower respiratory tract infections, although they are classically associated with either lymphoproliferative disorders or malignancy. GLILD (usually presenting in CVID), chronic granulomatous disease, and immune dysregulation (including hemophagocytic lymphohistiocytosis and autoimmune lymphoproliferative syndrome) are common lymphoproliferative PIDs associated with pulmonary adenopathies. Primary lymphoma (extranodal marginal zone B-cell lymphoma of mucosa-associated lymphoid tissue due to increased genetic vulnerability to Epstein-Barr virus-induced complications) $[120,121]$ and secondary lung metastatic malignancy (in PAD and CID patients with DNA repair system defects, NK-cell defects, and cytotoxic T-cell defects) may present initially with thoracic adenopathy [122124]. Infiltration of the lung with metastases and subsequent restrictive disease is more common than primary lung tumors.

Pulmonary adenopathies and malignancies could lead indirectly to pulmonary arterial hypertension and superior vena cava syndrome. Malignancy is the second most common cause of death in PID (6\%-10\% worldwide).

\section{Hyperreactive Airway Diseases}

Patients with PAD, especially CVID and SIgAD (15\%-45\% of patients), may have a concomitant history of asthma and other types of hyperreactive airway diseases, although it can be difficult to differentiate between these atopic complications in severe pulmonary conditions $[50,125,126]$. Both asthma and small hyperreactive airway diseases can cause dyspnea, wheezing, cough, and sputum production. Detection of both conditions is confirmed by the presence of a reversible obstructive pattern in pulmonary function tests and a positive result in the methacholine provocation test.

\section{Pulmonary Dysgenesis}

Velocardiofacial syndrome (also known as DiGeorge syndrome, affecting $10 \%$ of patients) is a hereditary congenital disease that could be associated with immunodeficiency if it involves impaired thymic development due to $22 \mathrm{q} 11.2$ deletion. However, in some affected individuals, pulmonary dysgenesis and other structural airway abnormalities may be present in addition to abnormal development of the pharyngeal arch. On the other hand, in cardiac defects, pulmonary artery anomalies such as pulmonary atresia and absent pulmonary valve syndrome can affect lung function [127].

\section{Pulmonary Complications of PID Treatment}

Pulmonary adverse effects associated with immunoglobulin therapy can be classed as immediate reactions (flu-like symptoms, hypersensitivity reaction, and transfusion-related acute lung injury) and delayed reactions (mainly due to thromboembolic events) [128].

Pulmonary graft-versus-host disease (GVHD) is one of the respiratory complications that can be observed in PID patients with severe CID-induced lack of maternal T-cell engraftment or in other types of PID after HSCT [129]. Pulmonary GVHD can be acute (rare, occurring around 5 months after transplantation with perihilar or diffuse interstitial fibrosis, pulmonary cysts, and pulmonary nodules) or chronic (usually presents as BOOP) [130].

\section{Conclusions}

The respiratory system is the most frequent site of the clinical manifestations in PID and associated complications are often the first warning sign of PID. Pulmonary complications must be recognized and diagnosed accurately in patients with PID, since they determine prognosis. Since pulmonary complications could be considered a significant cause of morbidity and mortality in PID patients, appropriate awareness of these manifestations is essential, especially for the pulmonologist.

\section{Funding}

The authors declare that no funding was received for the present study.

\section{Conflicts of Interest}

The authors declare that they have no conflicts of interest.

\section{References}

1. Lee PP, Lau YL. Primary immunodeficiencies: "new" disease in an old country. Cell Mol Immunol. 2009;6:397-406.

2. Azizi G, Ghanavatinejad A, Abolhassani H, Yazdani R, Rezae $\mathrm{N}$, Mirshafiey A, Aghamohammadi A. Autoimmunity in primary T-cell immunodeficiencies. Expert Rev Clin Immunol. 2016;12:989-1006.

3. Aghamohammadi $A$, Mohammadinejad $P$, Abolhassani $H$ Mirminachi B, Movahedi M, Gharagozlou M, Parvaneh N, Zeiaee V, Mirsaeed-Ghazi B, Chavoushzadeh Z, Mahdaviani A, Mansouri M, Yousefzadegan S, Sharifi B, Zandieh F, Hedayat E, Nadjafi A, Sherkat R, Shakerian B, SadeghiShabestari M, Hosseini RF, Jabbari-Azad F, Ahanchian $H$, Behmanesh F, Zandkarimi M, Shirkani A, Cheraghi T, Fayezi A, Mohammadzadeh I, Amin R, Aleyasin S, Moghtaderi M, Ghaffari J, Arshi S, Javahertrash N, Nabavi M, Bemanian MH, Shafiei A, Kalantari N, Ahmadiafshar A, Khazaei HA, Atarod L, Rezaei N. Primary immunodeficiency disorders in Iran: update and new insights from the third report of the national registry. J Clin Immunol. 2014;34:478-90.

4. Azizi G, Ahmadi M, Abolhassani H, Yazdani R, Mohammad $H$, Mirshafiey A, Rezaei N, Aghamohammadi A. Autoimmunity 
in Primary Antibody Deficiencies. Int Arch Allergy Immunol. 2016;171:180-93.

5. Rezaei N, Bonilla FA, Sullivan KE, de Vries E, Orange JS. An introduction to primary immunodeficiency diseases. In: Primary Immunodeficiency Diseases. Springer; 2008. p. 1-38.

6. Picard C, Al-Herz W, Bousfiha A, Casanova JL, Chatila T, Conley ME, Cunningham-Rundles C, Etzioni A, Holland SM, Klein C, Nonoyama S, Ochs HD, Oksenhendler E, Puck JM, Sullivan KE, Tang ML, Franco JL, Gaspar HB. Primary Immunodeficiency Diseases: an Update on the Classification from the International Union of Immunological Societies Expert Committee for Primary Immunodeficiency 2015. J Clin Immunol. 2015;35:696-726.

7. Azizi G, Abolhassani $H$, Rezaei N, Aghamohammadi A, Asgardoon MH, Rahnavard J, Dizaji MZ, Yazdani R. The Use of Immunoglobulin Therapy in Primary Immunodeficiency Diseases. Endocr Metab Immune Disord Drug Targets. 2016.

8. Jesenak M, Banovcin P, Jesenakova B, Babusikova E. Pulmonary manifestations of primary immunodeficiency disorders in children. Front Pediatr. 2014;2:77.

9. Azizi G, Abolhassani $H$, Asgardoon MH, Alinia T, Yazdani R, Mohammadi J, Rezaei N, Ochs HD, Aghamohammadi A. Autoimmunity in common variable immunodeficiency: epidemiology, pathophysiology and management. Expert Rev Clin Immunol. 2017;13:101-15.

10. Nonas S. Pulmonary Manifestations of Primary Immunodeficiency Disorders. Immunol Allergy Clin North Am. 2015;35:753-66.

11. Tarzi MD, Grigoriadou S, Carr SB, Kuitert LM, Longhurst HJ. Clinical immunology review series: An approach to the management of pulmonary disease in primary antibody deficiency. Clin Exp Immunol. 2009;155:147-55.

12. Membrila-Mondragon J, Staines-Boone AT, Sanchez-Sanchez LM, Ruiz-Pedraza MD. [Pulmonary complications in pediatric patients with primary immunodeficiency]. Gac Med Mex. 2015; 151:157-63.

13. Benninger MS, Ferguson BJ, Hadley JA, Hamilos DL, Jacobs M, Kennedy DW, Lanza DC, Marple BF, Osguthorpe JD, Stankiewicz JA, Anon J, Denneny J, Emanuel I, Levine H. Adult chronic rhinosinusitis: definitions, diagnosis, epidemiology, and pathophysiology. Otolaryngol Head Neck Surg. 2003;129:S132.

14. Arkwright PD, Gennery AR. Ten warning signs of primary immunodeficiency: a new paradigm is needed for the $21 \mathrm{st}$ century. Ann N Y Acad Sci. 2011;1238:7-14.

15. Yarmohammadi $H$, Estrella L, Doucette J, CunninghamRundles C. Recognizing primary immune deficiency in clinical practice. Clin Vaccine Immunol. 2006;13:329-32.

16. Mazza JM, Lin SY. Primary immunodeficiency and recalcitrant chronic sinusitis: a systematic review. Int Forum Allergy Rhinol. 2016:6:1029-33.

17. Aghamohammadi A, Moazzami K, Rezaei N, Karimi A, Movahedi M, Gharagozlou M, Abdollahzade S, Pouladi N, Kouhi A, Moin M. ENT manifestations in Iranian patients with primary antibody deficiencies. J Laryngol Otol. 2008;122:409-13.

18. Buehring I, Friedrich B, Schaaf J, Schmidt H, Ahrens P, Zielen $S$. Chronic sinusitis refractory to standard management in patients with humoral immunodeficiencies. Clin Exp Immunol. 1997;109:468-72.
19. Bernatowska E, Mikoluc B, Krzeski A, Piatosa B, Gromek I. Chronic rhinosinusitis in primary antibody immunodeficient patients. Int J Pediatr Otorhinolaryngol. 2006;70:1587-92.

20. Orange JS, Ballow M, Stiehm ER, Ballas ZK, Chinen J, De La Morena M, Kumararatne D, Harville TO, Hesterberg P, Koleilat M, McGhee S, Perez EE, Raasch J, Scherzer R, Schroeder H, Seroogy C, Huissoon A, Sorensen RU, Katial R. Use and interpretation of diagnostic vaccination in primary immunodeficiency: a working group report of the Basic and Clinical Immunology Interest Section of the American Academy of Allergy, Asthma \& Immunology. J Allergy Clin Immunol. 2012;130:S1-24.

21. Mokhtari M, Shakeri A, Mirminachi B, Abolhassani H, Yazdani R, Grimbacher B, Aghamohammadi A. Important Factors Influencing Severity of Common Variable Immunodeficiency. Arch Iran Med. 2016;19:544-50.

22. Chee L, Graham SM, Carothers DG, Ballas ZK. Immune dysfunction in refractory sinusitis in a tertiary care setting. Laryngoscope. 2001;111:233-5.

23. Mendieta-Flores E, Del-Rivero-Hernandez LG, Zavala-Perez $\mathrm{M}$, Segura-Mendez NH. [Rhinosinusitis and its impact on the quality of life in patients with common variable immunodeficiency]. Rev Alerg Mex. 2012;59:60-4.

24. Bonilla FA, Khan DA, Ballas ZK, Chinen J, Frank MM, Hsu JT, Keller M, Kobrynski LJ, Komarow HD, Mazer B, Nelson RP, Jr., Orange JS, Routes JM, Shearer WT, Sorensen RU, Verbsky JW, Bernstein DI, Blessing-Moore J, Lang D, Nicklas RA, Oppenheimer J, Portnoy JM, Randolph CR, Schuller D, Spector $\mathrm{SL}$, Tilles $\mathrm{S}$, Wallace D. Practice parameter for the diagnosis and management of primary immunodeficiency. J Allergy Clin Immunol. 2015;136:1186-205 e1-78.

25. Rusconi F, Panisi C, Dellepiane RM, Cardinale F, Chini L, Martire B, Bonelli N, Felisati G, Pietrogrande MC. Pulmonary and sinus diseases in primary humoral immunodeficiencies with chronic productive cough. Arch Dis Child. 2003;88:1101-5.

26. Khalid AN, Mace JC, Smith TL. Outcomes of sinus surgery in ambulatory patients with immune dysfunction. Am J Rhinol Allergy. 2010;24:230-3.

27. Lusk RP, Muntz HR. Endoscopic sinus surgery in children with chronic sinusitis: a pilot study. Laryngoscope. 1990;100:6548.

28. Weinberg EA, Brodsky L, Brody A, Pizzuto M, Stiner H. Clinical classification as a guide to treatment of sinusitis in children. Laryngoscope. 1997; 107:241-6.

29. Lusk RP, Polmar SH, Muntz HR. Endoscopic ethmoidectomy and maxillary antrostomy in immunodeficient patients. Arch Otolaryngol Head Neck Surg. 1991;117:60-3.

30. Benninger MS, Sindwani R, Holy CE, Hopkins C. Early versus delayed endoscopic sinus surgery in patients with chronic rhinosinusitis: impact on health care utilization. Otolaryngol Head Neck Surg. 2015;152:546-52.

31. Owayed A, Al-Herz W. Sinopulmonary Complications in Subjects With Primary Immunodeficiency. Respir Care. 2016;61:1067-72.

32. Conley ME, Howard V. Clinical findings leading to the diagnosis of X-linked agammaglobulinemia. J Pediatr. 2002;141:566-71.

33. Leibovitz E, Broides A, Greenberg D, Newman N. Current management of pediatric acute otitis media. Expert Rev Anti Infect Ther. 2010;8:151-61. 
34. Winkelstein JA, Marino MC, Lederman HM, Jones SM, Sullivan K, Burks AW, Conley ME, Cunningham-Rundles C, Ochs HD. X-linked agammaglobulinemia: report on a United States registry of 201 patients. Medicine (Baltimore). 2006;85:193-202.

35. Moin M, Aghamohammadi A, Farhoudi A, Pourpak Z, Rezaei N, Movahedi M, Gharagozlou M, Ghazi BM, Zahed A, Abolmaali K, Mahmoudi M, Emami L, Bashashati M. X-linked agammaglobulinemia: a survey of 33 Iranian patients. Immunol Invest. 2004;33:81-93.

36. Aghamohammadi $A$, Abolhassani $H_{\text {, Latif }} A_{\text {, Tabassomi }} F_{i}$ Shokuhfar T, Torabi Sagvand B, Shahinpour S, Mirminachi B, Parvaneh N, Movahedi M, Gharagozlou M, Sherkat R, Amin $R$, Aleyasin $S$, Faridhosseini $R$, Jabbari-Azad $F$, Cheraghi $T$ Eslamian MH, Khalili A, Kalantari N, Shafiei A, Dabbaghzade A, Khayatzadeh A, Ebrahimi M, Razavinejad D, Bazregari S, Ghaffari J, Bemanian MH, Behniafard N, Kashef S, Mohammadzadeh I, Hammarstrom L, Rezaei N. Long-term evaluation of a historical cohort of Iranian common variable immunodeficiency patients. Expert Rev Clin Immunol. 2014;10:1405-17.

37. Urschel S, Kayikci L, Wintergerst U, Notheis G, Jansson A, Belohradsky BH. Common variable immunodeficiency disorders in children: delayed diagnosis despite typical clinical presentation. J Pediatr. 2009;154:888-94.

38. Martinez Garcia MA, de Rojas MD, Nauffal Manzur MD, Munoz Pamplona MP, Compte Torrero L, Macian V, Perpina Tordera M. Respiratory disorders in common variable immunodeficiency. Respir Med. 2001;95:191-5.

39. Ogershok PR, Hogan MB, Welch JE, Corder WT, Wilson NW. Spectrum of illness in pediatric common variable immunodeficiency. Ann Allergy Asthma Immunol. 2006;97: 653-6.

40. Epstein MM, Gruskay F. Selective deficiency in pneumococcal antibody response in children with recurrent infections. Ann Allergy Asthma Immunol. 1995;75:125-31.

41. Wolpert J, Knutsen AP. Natural history of selective antibody deficiency to bacterial polysaccharide antigens in children. Pediatr Allergy Immunol Pulmonol. 1998;12:183-91.

42. French MA, Denis KA, Dawkins R, Peter JB. Severity of infections in IgA deficiency: correlation with decreased serum antibodies to pneumococcal polysaccharides and decreased serum IgG2 and/or IgG4. Clin Exp Immunol. 1995; 100:47-53.

43. Yazdani R, Latif A, Tabassomi F, Abolhassani H, Azizi G, Rezaei $\mathrm{N}$, Aghamohammadi A. Clinical phenotype classification for selective immunoglobulin A deficiency. Expert Rev Clin Immunol. 2015;11:1245-54.

44. Yazdani R, Azizi G, Abolhassani H, Aghamohammadi A. Selective IgA Deficiency: Epidemiology, Pathogenesis, Clinical Phenotype, Diagnosis, Prognosis and Management. Scand I Immunol. 2017:85:3-12.

45. Veenhoven R, Rijkers G, Schilder A, Adelmeijer J, Uiterwaal C, Kuis W, Sanders E. Immunoglobulins in otitis-prone children. Pediatr Res. 2004;55:159-62.

46. Bierry G, Boileau J, Barnig C, Gasser B, Korganow AS, Buy $X$, Jeung MY, Roy C, Gangi A. Thoracic manifestations of primary humoral immunodeficiency: a comprehensive review. Radiographics. 2009;29:1909-20.

47. Touw $C M$, van de Ven AA, de Jong PA, Terheggen-Lagro $S$, Beek E, Sanders EA, van Montfrans JM. Detection of pulmonary complications in common variable immunodeficiency. Pediatr Allergy Immunol. 2010;21:793-805.
48. Rezaei N, Aghamohammadi A, Moin M, Pourpak Z, Movahedi M, Gharagozlou M, Atarod L, Ghazi BM, Isaeian A, Mahmoudi M, Abolmaali K, Mansouri D, Arshi S, Tarash NJ, Sherkat R, Akbari H, Amin R, Alborzi A, Kashef S, Farid R, Mohammadzadeh I, Shabestari MS, Nabavi M, Farhoudi A. Frequency and clinical manifestations of patients with primary immunodeficiency disorders in Iran: update from the Iranian Primary Immunodeficiency Registry. J Clin Immunol. 2006;26:519-32.

49. Cunningham-Rundles C, Bodian C. Common variable immunodeficiency: clinical and immunological features of 248 patients. Clin Immunol. 1999;92:34-48.

50. Busse PJ, Farzan S, Cunningham-Rundles C. Pulmonary complications of common variable immunodeficiency. Ann Allergy Asthma Immunol. 2007;98:1-8; quiz -11, 43.

51. HermaszewskiRA,WebsterAD.Primaryhypogammaglobulinaemia: a survey of clinical manifestations and complications. Q J Med. 1993;86:31-42.

52. Gathmann B, Mahlaoui N, Gerard L, Oksenhendler E, Warnatz K, Schulze I, Kindle G, Kuijpers TW, van Beem RT, Guzman D, Workman S, Soler-Palacin P, De Gracia J, Witte T, Schmidt RE, Litzman J, Hlavackova E, Thon V, Borte M, Borte S, Kumararatne D, Feighery C, Longhurst $H$, Helbert M, Szaflarska A, Sediva A, Belohradsky BH, Jones A, Baumann U, Meyts I, Kutukculer N, Wagstrom P, Galal NM, Roesler J, Farmaki E, Zinovieva N, Ciznar P, Papadopoulou-Alataki E, Bienemann K, Velbri S, Panahloo Z, Grimbacher B. Clinical picture and treatment of 2212 patients with common variable immunodeficiency. J Allergy Clin Immunol. 2014;134:116-26.

53. Winkelstein JA, Marino MC, Ochs $H$, Fuleihan $R$, Scholl $P R_{\text {, }}$ Geha R, Stiehm ER, Conley ME. The X-linked hyper-IgM syndrome: clinical and immunologic features of 79 patients. Medicine (Baltimore). 2003;82:373-84.

54. Hanson EP, Monaco-Shawver L, Solt LA, Madge LA, Banerjee PP, May MJ, Orange JS. Hypomorphic nuclear factor-kappaB essential modulator mutation database and reconstitution system identifies phenotypic and immunologic diversity. J Allergy Clin Immunol. 2008;122:1169-77 e16.

55. Sullivan $K E$, Mullen $C A$, Blaese RM, Winkelstein JA. A multiinstitutional survey of the Wiskott-Aldrich syndrome. J Pediatr. 1994;125:876-85.

56. Orange JS, Grossman WJ, Navickis RJ, Wilkes MM. Impact of trough $\lg G$ on pneumonia incidence in primary immunodeficiency: A meta-analysis of clinical studies. Clin Immunol. 2010;137:21-30.

57. Dale DC, Cottle TE, Fier CJ, Bolyard AA, Bonilla MA, Boxer $L A$, Cham B, Freedman MH, Kannourakis G, Kinsey $S E$, Davis R, Scarlata D, Schwinzer B, Zeidler C, Welte K. Severe chronic neutropenia: treatment and follow-up of patients in the Severe Chronic Neutropenia International Registry. Am J Hematol. 2003;72:82-93.

58. Blackburn MR, Kellems RE. Adenosine deaminase deficiency: metabolic basis of immune deficiency and pulmonary inflammation. Adv Immunol. 2005;86:1-41.

59. Kinkade S, Long NA. Acute Bronchitis. Am Fam Physician. 2016;94:560-5.

60. Kalicki B, Kapusta K, Śniady A, Heropolitańska-Pliszka E, Mierzejewska A, Jung A. Common variable immunodeficiency - case report. Centr Eur J Immunol. 2013;38:141-8. 
61. Karaulov AV, Sidorenko IV, Kapustina AS. Major approaches in early diagnostics of common variable immunodeficiency in adults in Moscow. F1000Res. 2012;1:46.

62. Plebani A, Soresina A, Rondelli R, Amato GM, Azzari C, Cardinale F, Cazzola G, Consolini R, De Mattia D, Dell'Erba G, Duse M, Fiorini M, Martino S, Martire B, Masi M, Monafo V, Moschese V, Notarangelo LD, Orlandi P, Panei P, Pession A, Pietrogrande MC, Pignata C, Quinti I, Ragno V, Rossi P, Sciotto A, Stabile A. Clinical, immunological, and molecular analysis in a large cohort of patients with X-linked agammaglobulinemia: an Italian multicenter study. Clin Immunol. 2002;104:221-30.

63. Kim JH, Park S, Hwang YI, Jang SH, Jung KS, Sim YS, Kim CH, Kim C, Kim DG. Immunoglobulin G Subclass Deficiencies in Adult Patients with Chronic Airway Diseases. J Korean Med Sci. 2016;31:1560-5.

64. Piaggio G, Pinol AP. Use of the equivalence approach in reproductive health clinical trials. Stat Med. 2001;20:3571-7.

65. Pasteur MC, Helliwell SM, Houghton SJ, Webb SC, Foweraker JE, Coulden RA, Flower CD, Bilton D, Keogan MT. An investigation into causative factors in patients with bronchiectasis. Am J Respir Crit Care Med. 2000;162:1277-84.

66. Shoemark A, Ozerovitch L, Wilson R. Aetiology in adult patients with bronchiectasis. Respir Med. 2007;101:1163-70.

67. Gharagozlou M, Ebrahimi FA, Farhoudi A, Aghamohammadi A, Bemanian MH, Chavoshzadeh Z, Heidarzadeh M, Mehdizadeh M, Moin M, Movahedi M, Nabavi M, Pourpak Z, Rezaei N. Pulmonary complications in primary hypogammaglobulinemia: a survey by high resolution CT scan. Monaldi Arch Chest Dis. 2006;65:69-74.

68. Notarangelo LD, Plebani A, Mazzolari E, Soresina A, Bondioni MP. Genetic causes of bronchiectasis: primary immune deficiencies and the lung. Respiration. 2007;74:264-75.

69. Stead A, Douglas JG, Broadfoot CJ, Kaminski ER, Herriot R. Humoral immunity and bronchiectasis. Clin Exp Immunol. 2002;130:325-30.

70. Tabatabaie P, Aghamohammadi A, Mamishi S, Isaeian A, Heidari G, Abdollahzade S, Pirouzi P, Rezaei N, Heidarnazhad $H$, Mirsaeid Ghazi B, Yeganeh M, Cheraghi T, Abolhasani H, Saghafi S, Alizadeh H, Anaraki MR. Evaluation of humoral immune function in patients with bronchiectasis. Iran J Allergy Asthma Immunol. 2008;7:69-77.

71. Wood P, Stanworth S, Burton J, Jones A, Peckham DG, Green T, Hyde C, Chapel H. Recognition, clinical diagnosis and management of patients with primary antibody deficiencies: a systematic review. Clin Exp Immunol. 2007;149:410-23.

72. Thickett KM, Kumararatne DS, Banerjee AK, Dudley $R$, Stableforth DE. Common variable immune deficiency: respiratory manifestations, pulmonary function and highresolution CT scan findings. QJM. 2002;95:655-62.

73. Lieberman-Maran L, Orzano IM, Passero MA, Lally EV. Bronchiectasis in rheumatoid arthritis: report of four cases and a review of the literature--implications for management with biologic response modifiers. Semin Arthritis Rheum. 2006;35:379-87.

74. Li AM, Sonnappa S, Lex C, Wong E, Zacharasiewicz A, Bush A, Jaffe A. Non-CF bronchiectasis: does knowing the aetiology lead to changes in management? Eur Respir J. 2005;26:8-14.

75. Rodrigo MJ, Miravitlles M, Cruz MJ, de Gracia J, Vendrell M, Pascual C, Morell F. Characterization of specific immunoglobulin $G(\lg G)$ and its subclasses ( $\lg G 1$ and $\lg G 2$ ) against the 23-valent pneumococcal vaccine in a healthy adult population: proposal for response criteria. Clin Diagn Lab Immunol. 1997;4:168-72.

76. Aghamohammadi A, Allahverdi A, Abolhassani $H_{\text {, }}$ Moazzami K, Alizadeh H, Gharagozlou M, Kalantari N, Sajedi V, Shafiei A, Parvaneh N, Mohammadpour M, Karimi $N$, Sadaghiani MS, Rezaei N. Comparison of pulmonary diseases in common variable immunodeficiency and X-linked agammaglobulinaemia. Respirology. 2010;15:289-95.

77. Umetsu DT, Ambrosino DM, Quinti I, Siber GR, Geha RS. Recurrent sinopulmonary infection and impaired antibody response to bacterial capsular polysaccharide antigen in children with selective lgG-subclass deficiency. N Engl J Med. 1985;313:1247-51.

78. De Gracia J, Rodrigo MJ, Morell F, Vendrell M, Miravitlles M, Cruz MJ, Codina R, Bofill JM. IgG subclass deficiencies associated with bronchiectasis. Am J Respir Crit Care Med. 1996;153:650-5.

79. Hill SL, Mitchell JL, Burnett D, Stockley RA. IgG subclasses in the serum and sputum from patients with bronchiectasis. Thorax. 1998:53:463-8.

80. van Kessel DA, van Velzen-Blad H, van den Bosch JM, Rijkers GT. Impaired pneumococcal antibody response in bronchiectasis of unknown aetiology. Eur Respir J. 2005;25:482-9.

81. Miravitlles $M$, Vendrell $M$, de Gracia J. Antibody deficiency in bronchiectasis. Eur Respir J. 2005;26:178-80.

82. Vendrell M, de Gracia J, Rodrigo MJ, Cruz MJ, Alvarez A, Garcia M, Miravitlles M. Antibody production deficiency with normal IgG levels in bronchiectasis of unknown etiology. Chest. 2005;127:197-204.

83. Go ES, Ballas ZK. Anti-pneumococcal antibody response in normal subjects: a meta-analysis. J Allergy Clin Immunol. 1996:98:205-15.

84. Nikolaizik WH, Warner JO. Aetiology of chronic suppurative lung disease. Arch Dis Child. 1994;70:141-2.

85. Holland SM, DeLeo FR, Elloumi HZ, Hsu AP, Uzel G, Brodsky N, Freeman AF, Demidowich A, Davis J, Turner ML, Anderson VL, Darnell DN, Welch PA, Kuhns DB, Frucht DM, Malech HL, Gallin Jl, Kobayashi SD, Whitney AR, Voyich JM, Musser JM, Woellner C, Schaffer AA, Puck JM, Grimbacher B. STAT3 mutations in the hyper-IgE syndrome. N Engl J Med. 2007;357:1608-19.

86. Andrews T, Sullivan KE. Infections in patients with inherited defects in phagocytic function. Clin Microbiol Rev. 2003; 16:597-621.

87. Brown JS, Baxendale $H$, Floto RA. Immunodeficiencies associated with bronchiectasis. IMMUNODEFICIENCY2011. p. 178-91.

88. Gadola SD, Moins-Teisserenc HT, Trowsdale J, Gross WL, Cerundolo V. TAP deficiency syndrome. Clin Exp Immunol. 2000;121:173-8

89. Manson D, Reid B, Dalal I, Roifman CM. Clinical utility of high-resolution pulmonary computed tomography in children with antibody deficiency disorders. Pediatr Radiol. 1997;27:794-8.

90. Kainulainen L, Varpula M, Liippo K, Svedstrom E, Nikoskelainen J, Ruuskanen O. Pulmonary abnormalities in patients with primary hypogammaglobulinemia. J Allergy Clin Immunol. 1999;104:1031-6. 
91. Obregon RG, Lynch DA, Kaske T, Newell JD, Jr., Kirkpatrick $\mathrm{CH}$. Radiologic findings of adult primary immunodeficiency disorders. Contribution of CT. Chest. 1994;106:490-5.

92. Haidopoulou K, Calder A, Jones A, Jaffe A, Sonnappa S. Bronchiectasis secondary to primary immunodeficiency in children: longitudinal changes in structure and function. Pediatr Pulmonol. 2009;44:669-75.

93. Aghamohammadi A, Moin M, Kouhi A, Mohagheghi MA, Shirazi A, Rezaei N, Tavassoli S, Esfahani M, Cheraghi T, Dastan J, Nersesian J, Ghaffari SR. Chromosomal radiosensitivity in patients with common variable immunodeficiency. Immunobiology. 2008;213:447-54.

94. Palanduz S, Palanduz A, Yalcin I, Somer A, Ones U, Ustek D, Ozturk S, Salman N, Guler N, Bilge H. In vitro chromosomal radiosensitivity in common variable immune deficiency. Clin Immunol Immunopathol. 1998;86:180-2.

95. Nahas SA, Gatti RA. DNA double strand break repair defects, primary immunodeficiency disorders, and 'radiosensitivity'. Curr Opin Allergy Clin Immunol. 2009;9:510-6.

96. Serra G, Milito C, Mitrevski M, Granata G, Martini H, Pesce AM, Sfika I, Bonanni L, Catalano C, Fraioli F, Quinti I. Lung MRI as a possible alternative to CT scan for patients with primary immune deficiencies and increased radiosensitivity. Chest. 2011;140:1581-9.

97. Rezaei N, Abolhassani H, Aghamohammadi A, Ochs HD. Indications and safety of intravenous and subcutaneous immunoglobulin therapy. Expert Rev Clin Immunol. 2011;7:301-16.

98. Vidarsson G, Dekkers G, Rispens T. IgG subclasses and allotypes: from structure to effector functions. Front Immunol. 2014;5:520.

99. Tafuro F, Corradi M. An approach to interpreting restrictive spirometric pattern results in occupational settings. Med Lav. 2016;107:419-36.

100. Vizioli L, Ciccarese F, Forti $P$, Chiesa AM, Giovagnoli $M$, Mughetti M, Zompatori M, Zoli M. Integrated Use of Lung Ultrasound and Chest X-Ray in the Detection of Interstitial Lung Disease. Respiration. 2017;93:15-22.

101. Feydy A, Sibilia J, De Kerviler E, Zagdanski AM, Chevret S, Fermand JP, Brouet JC, Frija J. Chest high resolution CT in adults with primary humoral immunodeficiency. Br J Radiol. 1996;69:1108-16.

102. Maglione PJ, Ko HM, Beasley MB, Strauchen JA, CunninghamRundles C. Tertiary lymphoid neogenesis is a component of pulmonary lymphoid hyperplasia in patients with common variable immunodeficiency. J Allergy Clin Immunol. 2014;133:535-42.

103. Park JH, Levinson Al. Granulomatous-lymphocytic interstitial lung disease (GLILD) in common variable immunodeficiency (CVID). Clin Immunol. 2010;134:97-103.

104. Aghamohammadi A, Abolhassani H, Rezaei N, Kalantari N, Tamizifar B, Cheraghi T, Parvaneh N, Yeganeh $M$, Moazzami K, Ebrahimi-Daryani N, Anaraki MR. Cutaneous granulomas in common variable immunodeficiency: case report and review of literature. Acta Dermatovenerol Croat. 2010;18:107-13.

105. Aukrust P, Lien E, Kristoffersen AK, Muller F, Haug CJ, Espevik T, Froland SS. Persistent activation of the tumor necrosis factor system in a subgroup of patients with common variable immunodeficiency--possible immunologic and clinical consequences. Blood. 1996;87:674-81.

106. Lopez-Herrera G, Tampella G, Pan-Hammarstrom Q, Herholz $P$, Trujillo-Vargas CM, Phadwal K, Simon AK, Moutschen $M$, Etzioni A, Mory A, Srugo I, Melamed D, Hultenby K, Liu C, Baronio $M$, Vitali M, Philippet P, Dideberg V, Aghamohammadi A, Rezaei N, Enright V, Du L, Salzer U, Eibel H, Pfeifer D, Veelken $H$, Stauss $H$, Lougaris V, Plebani A, Gertz EM, Schaffer AA, Hammarstrom L, Grimbacher B. Deleterious mutations in LRBA are associated with a syndrome of immune deficiency and autoimmunity. Am J Hum Genet. 2012;90:986-1001.

107. Bronsky D, Dunn YO. SARCOIDOSIS WITH HYPOGAMMAGLOBULINEMIA. Am J Med Sci. 1965;250:11-8.

108. Fasano MB, Sullivan KE, Sarpong SB, Wood RA, Jones SM, Johns CJ, Lederman HM, Bykowsky MJ, Greene JM, Winkelstein JA. Sarcoidosis and common variable immunodeficiency. Report of 8 cases and review of the literature. Medicine (Baltimore). 1996;75:251-61.

109. Malphettes M, Gerard L, Carmagnat M, Mouillot G, Vince N, Boutboul D, Berezne A, Nove-Josserand R, Lemoing V, Tetu L, Viallard JF, Bonnotte B, Pavic M, Haroche J, Larroche C, Brouet JC, Fermand JP, Rabian C, Fieschi C, Oksenhendler E. Lateonset combined immune deficiency: a subset of common variable immunodeficiency with severe T cell defect. Clin Infect Dis. 2009;49:1329-38.

110. Bates CA, Ellison MC, Lynch DA, Cool CD, Brown KK, Routes JM. Granulomatous-lymphocytic lung disease shortens survival in common variable immunodeficiency. J Allergy Clin Immunol. 2004;114:415-21.

111. Rao N, Mackinnon AC, Routes JM. Granulomatous and lymphocytic interstitial lung disease: a spectrum of pulmonary histopathologic lesions in common variable immunodeficiency-histologic and immunohistochemical analyses of 16 cases. Hum Pathol. 2015;46:1306-14.

112. Jolles $S$, Carne $E$, Brouns $M$, El-Shanawany $T$, Williams $P_{i}$ Marshall C, Fielding P. FDG PET-CT imaging of therapeutic response in granulomatous lymphocytic interstitial lung disease (GLILD) in common variable immunodeficiency (CVID). Clin Exp Immunol. 2017;187:138-45.

113. van de Ven $A A$, de Jong PA, Hoytema van Konijnenburg DP, Kessels OA, Boes M, Sanders EA, Terheggen-Lagro SW, van Montfrans JM. Airway and interstitial lung disease are distinct entities in paediatric common variable immunodeficiency. Clin Exp Immunol. 2011;165:235-42.

114. Boursiquot JN, Gerard L, Malphettes M, Fieschi C, Galicier $L$, Boutboul D, Borie R, Viallard JF, Soulas-Sprauel P, Berezne A, Jaccard A, Hachulla E, Haroche J, Schleinitz N, Tetu L, Oksenhendler E. Granulomatous disease in CVID: retrospective analysis of clinical characteristics and treatment efficacy in a cohort of 59 patients. J Clin Immunol. 2013;33:84-95.

115. Deerojanawong J, Chang AB, Eng PA, Robertson CF, Kemp AS. Pulmonary diseases in children with severe combined immune deficiency and DiGeorge syndrome. Pediatr Pulmonol. 1997;24:324-30.

116. Ito M, Nakagawa A, Hirabayashi N, Asai J. Bronchiolitis obliterans in ataxia-telangiectasia. Virchows Arch. 1997;430:131-7.

117. Shokri S, Nabavi M, Hirschmugl T, Aghamohammadi A, Arshi S, Bemanian MH, Fallahpour M, Molatefi R, Rekabi M, Eslami 
N, Ahmadian J, Darabi K, Sedighi GR, Monajemzadeh M, Modaresi M, Parvaneh N, Boztug K, Rezaei N. LPS-Responsive Beige-Like Anchor Gene Mutation Associated With Possible Bronchiolitis Obliterans Organizing Pneumonia Associated With Hypogammaglobulinemia and Normal IgM Phenotype and Low Number of B Cells. Acta Med Iran. 2016;54:620-3.

118. Snook NJ, Sharafat MA. Anaesthesia and intensive care for patients with transmissible diseases. Anaesth Intensive Care Med. 2013;14:43-7.

119. Boujaoude Z, Arya R, Rafferty W, Dammert P. Organising pneumonia in common variable immunodeficiency. BMJ Case Rep. 2013;2013.

120. Alkhairy OK, Perez-Becker R, Driessen GJ, Abolhassani $H$, van Montfrans J, Borte S, Choo S, Wang N, Tesselaar K, Fang M, Bienemann K, Boztug K, Daneva A, Mechinaud F, Wiesel T, Becker C, Duckers G, Siepermann K, van Zelm MC, Rezaei N, van der Burg M, Aghamohammadi A, Seidel MG, Niehues T, Hammarstrom L. Novel mutations in TNFRSF7/CD27: Clinical, immunologic, and genetic characterization of human CD27 deficiency. J Allergy Clin Immunol. 2015;136:703-12 e10.

121. Abolhassani $H$, Edwards ES, Ikinciogullari $A$, Jing $H$, Borte $S$, Buggert M, Du L, Matsuda-Lennikov M, Romano R, Caridha R, Bade S, Zhang Y, Frederiksen J, Fang M, Bal SK, Haskologlu S, Dogu F, Tacyildiz N, Matthews HF, McElwee JJ, Gostick E, Price DA, Palendira U, Aghamohammadi A, Boisson B, Rezaei N, Karlsson AC, Lenardo MJ, Casanova JL, Hammarstrom L, Tangye SG, Su HC, Pan-Hammarstrom Q. Combined immunodeficiency and Epstein-Barr virus-induced B cell malignancy in humans with inherited CD70 deficiency. J Exp Med. 2017;214:91-106.

122. Salavoura K, Kolialexi A, Tsangaris G, Mavrou A. Development of cancer in patients with primary immunodeficiencies. Anticancer Res. 2008;28:1263-9.

123. Mortaz E, Tabarsi P, Mansouri D, Khosravi A, Garssen J, Velayati A, Adcock IM. Cancers Related to Immunodeficiencies: Update and Perspectives. Front Immunol. 2016;7:365.

124. Shapiro RS. Malignancies in the setting of primary immunodeficiency: Implications for hematologists/oncologists. Am J Hematol. 2011;86:48-55.

125. Aghamohammadi A, Cheraghi T, Gharagozlou M, Movahedi M, Rezaei N, Yeganeh M, Parvaneh N, Abolhassani H, Pourpak Z, Moin M. IgA deficiency: correlation between clinical and immunological phenotypes. J Clin Immunol. 2009;29:130-6.

126. Yazdani R, Heydari A, Azizi G, Abolhassani H,Aghamohammadi A. Asthma and Allergic Diseases in a Selected Group of Patients With Common Variable Immunodeficiency. J Investig Allergol Clin Immunol. 2016;26:209-11.

127. Burnside RD. 22q11.21 Deletion Syndromes: A Review of Proximal, Central, and Distal Deletions and Their Associated Features. Cytogenet Genome Res. 2015;146:89-99.
128. Azizi $G$, Abolhassani $H$, Asgardoon $M H$, Shaghaghi $S$, Negahdari B, Mohammadi J, Rezaei N, Aghamohammadi A. Managing patients with side effects and adverse events to immunoglobulin therapy. Expert Rev Clin Pharmacol. 2016;9:91-102.

129. Muller S, Ege M, Pottharst A, Schulz AS, Schwarz K, Friedrich W. Transplacentally acquired maternal T lymphocytes in severe combined immunodeficiency: a study of 121 patients. Blood. 2001; 98: 1847-51.

130. Assi MA, Pulido JS, Peters SG, McCannel CA, Razonable RR. Graft-vs.-host disease in lung and other solid organ transplant recipients. Clin Transplant. 2007;21:1-6.

131. Martinot M, Oswald L, Parisi E, Etienne E, Argy N, Grawey I, De Briel D, Zadeh MM, Federici L, Blaison G, Koebel C, Jaulhac B, Hansmann Y, Christmann D. Immunoglobulin deficiency in patients with Streptococcus pneumoniae or Haemophilus influenzae invasive infections. Int J Infect Dis. 2014;19:79-84.

132.Pettigrew HD, Teuber SS, Gershwin ME. Clinical significance of complement deficiencies. Ann N Y Acad Sci. 2009;1173:108-23.

133. Picard C, Puel A, Bustamante J, Ku CL, Casanova JL. Primary immunodeficiencies associated with pneumococcal disease. Curr Opin Allergy Clin Immunol. 2003;3:451-9.

134. Ballow M. Primary immunodeficiency disorders: antibody deficiency. J Allergy Clin Immunol. 2002;109:581-91.

135. Roifman CM, Rao CP, Lederman HM, Lavi S, Quinn P, Gelfand EW. Increased susceptibility to Mycoplasma infection in patients with hypogammaglobulinemia. Am J Med. 1986;80:590-4.

136. Roberts D, Murray AE, Pratt BC, Meigh RE. Mycoplasma hominis as a respiratory pathogen in $X$-linked hypogammaglobulinaemia. J Infect. 1989;18:175-7.

137. Freeman AF, Davis J, Anderson VL, Barson W, Darnell DN, Puck JM, Holland SM. Pneumocystis jiroveci infection in patients with hyper-immunoglobulin E syndrome. Pediatrics. 2006;118:e1271-5.

138. Wolach B, Gavrieli R, Roos D, Berger-Achituv S. Lessons learned from phagocytic function studies in a large cohort of patients with recurrent infections. J Clin Immunol. 2012;32:454-66.

Manuscript received March 13, 2017; accepted for publication April 24, 2017.

\section{Asghar Aghamohammadi}

Children's Medical Center Hospital

62 Qarib St., Keshavarz Blvd.

Tehran14194, Iran

E-mail: aghamohammadi@sina.tums.ac.ir 